\title{
Porsild spruce in Canada - an update
}

\author{
by Rodney Arthur Savidge ${ }^{1}$
}

\begin{abstract}
Several new developments are noted since publication of "Porsild spruce in Canada" in The Forestry Chronicle in January 2013. Firstly, Porsild spruce has been found in northeastern Quebec. Secondly, although researchers were unaware of the fact until now, the Porsild spruce phenotype has been found to be a common component in the New Brunswick tree improvement program's second-generation seed orchard in support of reforestation. Thirdly, a wild tree discovered in New Brunswick displays morphological features of Engelmann spruce and, based on observed similarities between Yukon Beringia Porsild spruce phenotypes and the accepted Engelmann spruce phenotype, it is possible that the New Brunswick Engelmann spruce tree was derived from the local Porsild spruce population.
\end{abstract}

Keywords: Picea glauca (Moench) Voss, Picea glauca var. porsildii, Picea engelmannii Parry ex Engelm., Picea pungens Engelm., Engelmann spruce, interior spruce, Porsild spruce, white spruce, Yukon Beringia

\section{RÉSUMÉ}

Plusieurs faits nouveaux se sont fait jour depuis la publication de larticle sur « Lépinette de Porsild au Canada » dans le Forestry Chronicle de janvier 2013. Premièrement, on a trouvé de lépinette de Porsild dans le nord-est du Québec. Deuxièmement, on sest rendu compte que le phénotype de lépinette de Porsild se retrouve régulièrement dans les vergers à graines de deuxième génération du programme d’amélioration génétique des arbres du Nouveau-Brunswick à des fins de reboisement, et ce, même si les chercheurs nen étaient pas au fait lan dernier. Troisièmement, un arbre naturel découvert au Nouveau-Brunswick présente les caractéristiques morphologiques de l'épinette d'Engelmann et, d’après les similitudes constatées entre les phénotypes dépinette de Porsild du Yukon-Béringie et le phénotype reconnu de lépinette d’Engelmann, il se pourrait que le spécimen d’épinette d'Engelmann du Nouveau-Brunswick provienne de la population locale dépinette de Porsild.

Mots clés : Picea glauca (Moench) Voss, Picea glauca var. porsildii, Picea engelmannii Parry ex Engelm., Picea pungens Engelm., épinette d’Engelmann, épinette de l'intérieur, épinette de Porsild, épinette blanche, Yukon-Béringie

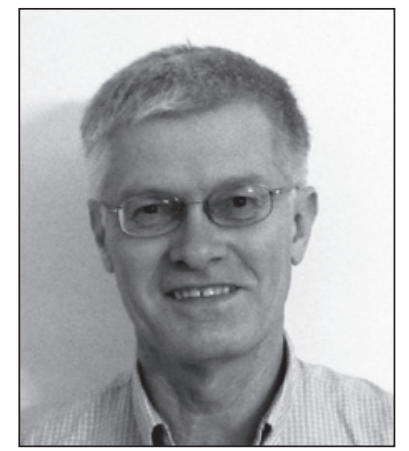

Rodney Arthur Savidge
On the advice of Dr. S. Payette (Conservateur, Herbier LouisMarie, Université Laval), the Porsild variety of white spruce occurs at two sites $\left(55.04012445^{\circ},-67.17138663^{\circ}\right.$ and $55.80562983^{\circ}$, $-68.17584367^{\circ}$ ) north of Schefferville, Quebec. This extends the northeastern range of Porsild spruce in Canada almost to the Labrador border and approximately $900 \mathrm{~km}$ farther east than was previously documented by $\mathrm{Ri}$ ley (1981), who found Porsild spruce on Akimiski Island in James Bay.

Secondly, this last summer it was observed that smooth blister-barked Porsild spruce trees are common within the New Brunswick tree improvement program's second-generation white spruce seed orchard managed by the New Brunswick Department of Natural Resources at Kingsclear, NB, in support of reforestation. Full quantitative data will be presented in a future report, but for now our observations support the interpretation that the Porsild spruce phenotype gained acceptance solely on the basis of its desirable field performance, in the absence of awareness that the Porsild blister-barked phenotype was being selected (T. Lutz, M. Fullarton and R. Savidge, unpublished data). The original white spruce ancestors of that second-generation seed orchard were plus trees found in wild populations distributed throughout New Brunswick, also including a few populations from Maine and Nova Scotia. First-generation trials to identify trees of superior growth and form began by grafting scions from selected wild plus trees onto white spruce rootstocks (wild pedigree) followed by assessment of controlpollinated progeny. Nursery stock was subsequently produced from seeds harvested from the first-generation grafts, and seedlings were planted at many sites in New Brunswick. After approximately a decade of growth and analysis of province-wide performance, better-performing trees were selected, and scions from those were again grafted onto rootstocks (wild pedigree) to produce the second-generation white spruce seed orchard trees at the Kingsclear, NB, nursery (M. Fullarton, DNRE, personal communication). Thus, following two selections, it appears that Porsild spruce is not merely native to Atlantic Canada as earlier noted (Savidge 2013). The Porsild spruce phenotype evidently is also among the better performers in relation to forest productivity.

A third observation concerns Engelmann spruce (Picea engelmannii Parry ex Engelm.). As previously noted (Savidge 
2013), a number of forest scientists have questioned whether Engelmann spruce should be regarded as a species, suggesting instead that it is so like white spruce, except in altitudinal distribution, that it may merely be another expression of white spruce. In New Brunswick, I recently encountered a tree at an altitude near sea level that by annual ring count is approximately 80 years old, and about $40 \mathrm{~cm} \mathrm{DBH}$ and $20 \mathrm{~m}$ in height. The features of its cones, seeds, needles and twigs fully satisfy, to my knowledge, the accepted description of Engelmann spruce, as the tree is known in western Canada (Fig. 1). This putative Engelmann spruce tree is growing in the midst of a wild mixed stand of eastern white pine (Pinus strobus L.), both Porsild and scaly-barked white spruce (Picea glauca [Moench] Voss), red spruce (Picea rubens Sarg.), eastern white-cedar (Thuja occidentalis L.), eastern hemlock (Tsuga canadensis [L.] Carr.), tamarack (Larix laricina [Du Roi] K. Koch), paper birch (Betula papyrifera Marsh.), trembling aspen (Populus tremuloides Michx.) and largetooth aspen (Populus grandidentata Michx..), all of which are also mature trees. The site supporting this putative Engelmann spruce tree clearly is occupied by a wild stand; thus, it is probable that the tree is truly a wild native tree of New Brunswick. The obvious question attending this novel observation is how an Engelmann spruce tree could possibly be natural to New Brunswick yet so distantly far east from and at such a low altitude below its generally perceived native range in western North America (e.g., see Habeck and Weaver 1969).

A possible solution to this dilemma is that the species known as Engelmann spruce may, by ancestry, be an evolutionary derivative of Porsild spruce. Engelmann spruce has been distinguished from white spruce primarily on the basis of higher altitude growth (Habeck and Weaver 1969), but that distinction fades now that Porsild spruce has been recognized to be capable of high-altitude growth (Savidge 2012, 2013). Moreover, high-altitude spruce saplings that have been interpreted as Engelmann spruce in western Canada not uncommonly display smooth resin-blistered bark like that of Porsild spruce (Habeck and Weaver 1969). Moreover, both the Porsild variety of white spruce and Engelmann spruce are predisposed to produce a cuticular wax giving the needles a bluish hue approaching that of Picea pungens Engelm. (R. A. Savidge, unpublished data). Thus, although the northern range of Engelmann spruce has been mapped to be far south of the Yukon's southern border, at least some Engelmann spruce phenotypes (or their perceived hybrids with white spruce) would, if transplanted northward, undoubtedly be interpreted as Porsild spruce trees.

The one notable difference between Engelmann and Porsild spruces appears to reside in cone features. Porsild spruce cone scales generally are not fimbrillated, nor do their outer ends taper, whereas "pure" Engelmann spruce trees have fimbrillated cone scales that taper at both ends, and the seeds have relatively small seed wings as compared to other spruce species (Fig. 1). The cones of supposed $P$. glauca $\times P$. engelmannii hybrids, designated as "interior spruce" within British Columbia, display varied degrees of cone-scale fimbrillation and tapering.

Within Yukon white spruce populations, the morphological diversity of Porsild spruce is readily apparent (Savidge 2012), and that diversity manifests the underlying genetic diversity that is well accepted as a predictable feature of glacial refugia. The morphological diversity within Yukon Beringia Porsild spruce populations extends to all observable features of their seed cones, including the shapes and amount of fimbrillation of cone scales (Fig. 2). Mountain populations of Porsild spruce surviving in Yukon Beringia are almost certainly descendents of ancient trees and, as suggested before, it deserves consideration that Porsild spruce populations in eastern Canada may also trace back to primeval pre-glacial Canadian forest (Savidge 2013). Admittedly, these for now are merely speculative ideas, but research to identify descendents of Canada's primeval preglacial forest seems a worthy call, as such trees are likely to have time-tested fitness to survive climate-change oscillations and the associated forest-health challenges. The solitary and highly novel putative Engelmann spruce tree that is growing in New Brunswick provides an important scientific opportunity and incentive to investigate, through molecular genetics research, how closely Engelmann and Porsild spruce trees are related.

\section{Acknowledgements}

I am grateful to Serge Payette for sharing information about new Porsild spruce sites in Quebec, and to the New Brunswick Department of Natural Resources, in particular Michele Fullarton and Kathy Tosh, for permission to investigate its
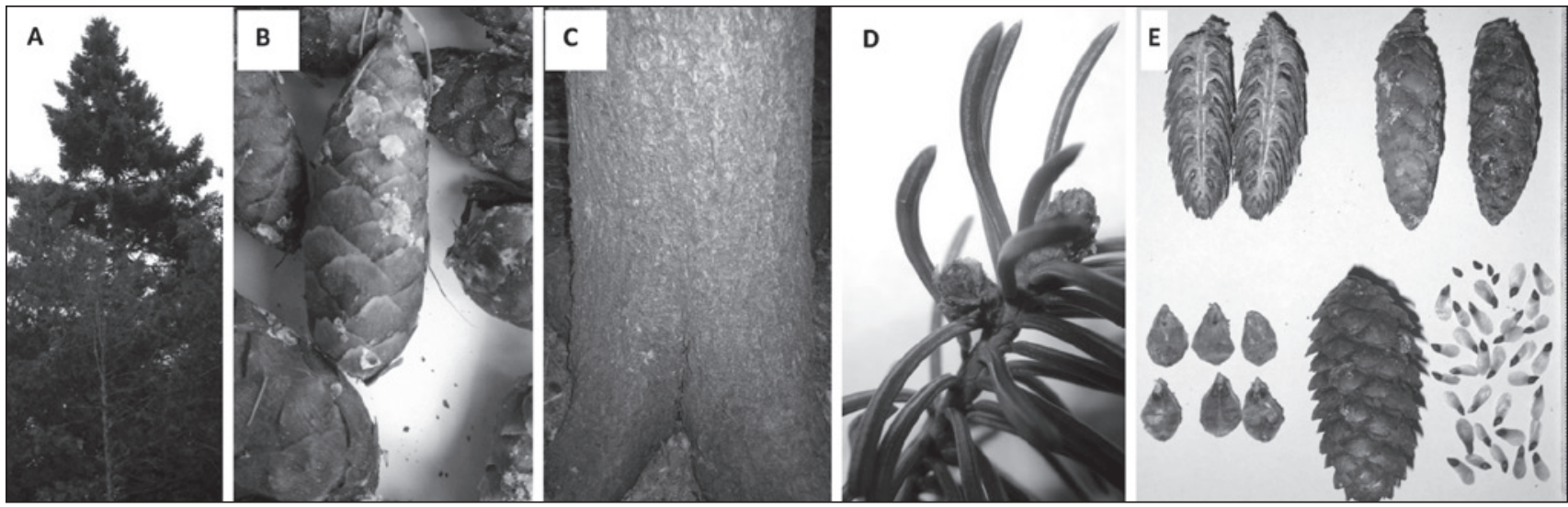

Fig. 1. Components of an Engelmann spruce tree found growing at $80 \mathrm{~m}$ a.s.l. in wild New Brunswick forest. $A$, upper half of the tree; $\mathrm{B}$, freshly fallen cones (colours varied, from green-brown and reddish-purple); C, trunk and root collar; D, needles and dormant buds; E, seed cone components: top left, a longitudinally bisected cone; top right, two unopened cones; bottom left, cone scales; bottom centre, a cone with reflexed scales; bottom right, seeds (the metric scale at right is in $\mathrm{mm}$ ). 


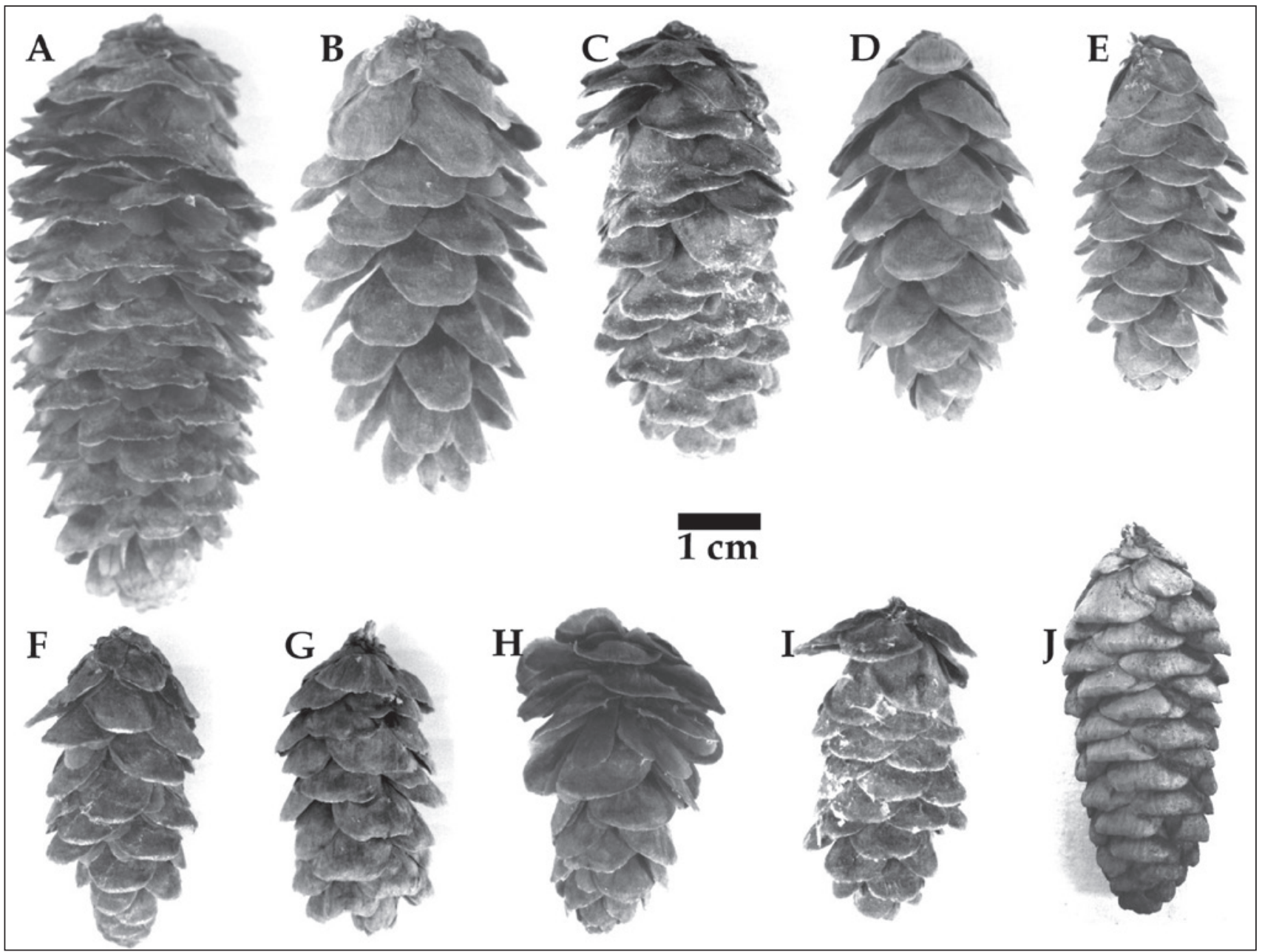

Fig. 2. Variation in open dry seed cones of Porsild spruce trees sampled at the following coordinates within Yukon Beringia: A, 64.1927, -139.9352; B, 64.1680, -139.8662; C, 63.8802, -139.0384; D, 64.1679, -139.8659; E, 64.1925, -139.9342; F, 64.1924, -139.9349; G, 62.1550, -137.5706; H, 62.0705, -136.4280; I, 64.1924, -139.9350; J, 69.0972, -140.0994. In addition to obvious variation in cone size and cone-scale numbers, slightly fimbrillated outer scale margins occur (cones A, B, G, I), and scales taper outward to narrower widths (cones B, D, E). Some cones (A, C, F, G, I, J) display scales having blunt or slightly concave outer margins whereas others (cones B, D, E, H) have convex outer margins. Scale bar $=1.00 \mathrm{~cm}$. The whiter appearance of some cone scales is due to varied amounts of solidified resin.

second-generation white spruce seed orchard. White spruce in Ivvavik National Park was sampled under Parks Canada Research and Collection Permit IVV-2012-11698, and I thank Dr. Donald McLennan for his assistance. The Yukon Tourism and Culture Department provided Scientist and Explorer licenses enabling my Yukon sampling, and Mr. G.J. Muff provided field assistance within Beringia. Reviewer comments were helpful in tempering my speculative ideas.

\section{References}

Habeck, J.R. and Weaver, T.W. 1969. A chemosystematic analysis of some hybrid spruce (Picea) populations in Montana. Can. J. Bot. 47: $1565-1570$.

Riley, J.L. 1981. The vascular flora of Akimiski Island, James Bay, N.W.T. Le Naturaliste canadien 108: 229-235.

Savidge, R. A. 2012. Yukon taiga - past, present and future, In N. Ishwaran (ed.). The Biosphere. pp. 63-92. InTech, Rijeka, Croatia. ISBN 978-953-51-0292-2.

Savidge, R.A. 2013. Porsild spruce in Canada. For. Chron. 89: 24-31. 